\title{
What Determines the Debt Policy of Listed Manufacturing Firms in Ghana?
}

\author{
Richard Kofi Akoto ${ }^{1} \&$ Dadson Awunyo-Vitor ${ }^{2}$ \\ ${ }^{1}$ Department of Banking and Finance, University of Professional Studies, Ghana \\ ${ }^{2}$ Department of Agricultural Economics, Agribusiness and Extension, Kwame Nkrumah University of Science \\ and Technology, Ghana \\ Correspondence: Dadson Awunyo-Vitor, Department of Agricultural Economics, Agribusiness and Extension, \\ Kwame Nkrumah University of Science and Technology, Kumasi, Ghana. Tel: 233(0)-208-152-298. E-mail: \\ Awunyovitor@yahoo.co.uk/dawunyo-vitor.ksb@knust.edu.gh
}

Received: September 1, 2013

Accepted: November 27, 2013

Online Published: December 23, 2013

doi: $10.5539 /$ ibr.v7n1p42

URL: http://dx.doi.org/10.5539/ibr.v7n1p42

\begin{abstract}
The purpose of this study is to examine the determinants of capital structure of listed manufacturing firms in Ghana. Data was collected from the annual reports of all the seven listed manufacturing firms in Ghana between 2000 and 2009. Panel regression methodology was used to analyse the data. The results revealed that listed manufacturing firms in Ghana use $17 \%$ equity capital and $83 \%$ debt capital to finance their operations. The debt structure is made up of $46 \%$ long term debt and $37 \%$ short term debt. However, it is observed that the firms tend to be more reliant on short-term sources of financing when specifically acquiring assets to expand and become profitable, which may be due to the under development of the Ghanaian capital market. The study also finds a positive and statistically significant relationship between total debt and asset structure but a positive and insignificant relationship between total debt and liquidity. Furthermore, it is revealed that size and profitability are also positive and statistically significant in their association with total debt. The study recommends that the Ghanaian government should take concrete steps to develop the country's capital market to enable businesses access long-term capital necessary for financial performance of the firm in the long run. It is further suggested that the Bank of Ghana (BoG) regulates the long-term lending rate of Ghanaian banks using moral suasion and other policy instruments.
\end{abstract}

Keywords: capital structure, manufacturing firms, panel regression, Ghana stock exchange

\section{Introduction}

Financing is an important aspect of managerial decision making. Debt and equity are the main sources of financing the long term activities of firms. According to Modigliani and Miller (1963), the profitability of firms largely depends on the extent to which firms use debt and equity in their operations. For the past few decades, the capital structure debate has gained considerable attention from both academic researchers and practitioners, however with much focus on developed economies. Equity capital is mainly ideal when the firm wishes to expand through the addition of new products and also when they desire to enter into new markets. The reason is that, depending on their dividend policy, firms can decide not to pay current dividends but rather channel these resources, which are relatively cheaper, to expand their operations (Modigliani \& Miller, 1963). On the other hand, debt must be considered by young fast growing firms, as these characteristics enable them to repay as scheduled (Akoto \& Gatsi, 2010).

The major theoretical underpinning of capital structure studies is rooted in the seminal work of Modigliani and Miller (1958). In their $M \& M$ theory, the authors argue that firms combine debt and equity to fund their long-term activities in a proportion that they think will maximise their value. According to Brigham and Ehrhardt (2002), most firms use several types of short-term debt to finance their working capital requirements. Some of these instruments are bank loans, trade credits, commercial paper and accruals. Demiguc-Kunt and Levine (2007) note that policy reforms that promote access to financial services should be at the core of the development agenda of nations. Better access to finance does not only increase economic growth, but also helps fight poverty. The World Bank Report (2007) observes that the failure of companies to have adequate access to finance acts as a brake on a nation's development (World Bank, 2007). 
In Ghana, capital structure studies are scanty and mainly geared towards the banking industry while neglecting equally important sectors. This may be due to the dominance of certain industries in the Ghanaian economy relative to the others. For example, because Ghana is an import-based economy, little attention has been paid to scholarly works in the manufacturing sector. However, it is crucial for us to note that research findings and recommendations in the Ghanaian manufacturing industry can largely unearth several important issues that need to be considered by investors and the government in developing the country's manufacturing base. This current study is an attempt in this direction as it contributes to the literature by investigating the factors that determine the capital structure decision of Ghanaian listed manufacturing firms. In achieving this, the study attempts to answer the following five (5) questions: 1) What is the relationship between debt policy and the size of listed manufacturing firms in Ghana? 2) What is the relationship between debt policy and profitability of listed manufacturing firms in Ghana? 3) How does liquidity affect the debt policy of listed manufacturing firms in Ghana? 4) How does asset structure affect the debt policy of listed manufacturing firms in Ghana? 5) What is the relationship between debt policy and growth of listed manufacturing firms in Ghana? The rest of the paper is divided in four sections. Section 2 is the review of the extant literature. Section 3 considers the research methodology. Section 4 presents and discusses the results, while section 5 concludes the paper.

\section{Empirical Literature}

As indicated earlier, the seminal work of Modigliani and Miller $(1958 ; 1963)$ on the relevance of debt policy for the modern firm has ignited an increase debate among academic researchers and practitioners. According to De Jong et al. (2008), the influence of firm-specific factors like: size, asset tangibility, profitability, firm risk and growth opportunities on debt policy vary from one country to another and also across industries due to country-specific and industry related factors. This implies that in making prudent capital structure decisions, country and industry specific studies are necessary to guide the managerial decision making process in this direction. This finding is further buttressed by Deesomsak et al. (2004) who also argue that the capital structure decision of firms is influenced by environmental and firm-specific factors. Furthermore, Antonius et al. (2002), using a panel data methodology, examine the debt policy of French, German and British firms. The authors observe that there is a positive and significant influence between a firm's size and leverage, implying that firms with large asset sizes use more debt. Perhaps, the low borrowing rates in these countries might have contributed to more debt usage by the firms as they expand. This study also confirms the findings of De Jong et al. (2008) and Deesomsak et al. (2004) that country and firm-specific factors influence capital structure decisions differently across country and industry.

In a related study, Frank and Vidhan (2005) found that firm size and asset tangibility relate positively with leverage while profitability presents an inverse association with it. This means that firms use more debt to acquire tangible assets than intangible assets, however, the profitability of the firm could be jeopardised as more and more debt is used. Furthermore, Hijazi and Tariq (2006), using OLS regression technique, maintain that firm size and profitability are negatively associated with leverage of Pakistani cement producing firms. This finding implies that profitable cement producing firms in Pakistan use more equity relative to debt in their operational activities. They further observe that asset tangibility and growth are also positively correlated with leverage. Additionally, Rao et al. (1995) conclude in their study that firm size and growth are inversely associated with debt. This means that smaller firms use more debt, and firms with better future prospects use more equity in their operations. In another study, Rajan and Zingales (1995) observed that in all G-7 countries, profitability is negatively related with leverage except in Germany. This finding reveals the ability of German firms to efficiently manage more debt relative to firms from other G-7 countries. On the other hand, the authors further discovered that firm size is positively associated with leverage in all the G-7 countries, but again, except in Germany. This further shows that smaller firms in Germany use more debt compared to their larger counterparts. However, they confirm that asset tangibility related positively with leverage in all the G-7 countries at the time of their study. Wolfgang and Fix (2003) conclude in their study that asset tangibility has a direct and significant influence on debt use and profitable firms use less leverage.

In Ghana, Akoto and Gatsi (2010) observed in their research that profitable banks in Ghana use about $87 \%$ of debt to fund their operations. This implies that in the Ghanaian context, banks must pursue aggressive deposit mobilisation policies to enable them to enhance their financial performance. This finding supports the finding of Amidu (2007) who earlier related that the capital structure of Ghanaian banks is mainly made up debt. In a related study, Abor (2005) argues that financially viable listed firms in Ghana use more short-term debt as their main source of financing. It is crucial for us to note that all the studies above have highlighted the significance of debt use in enhancing the financial performance of Ghanaian firms. The implication therefore is that government policies targeted at developing the debt market in Ghana are essential to further promote economic activity 
which is critical for economic growth and development. From the extant literature, it is therefore clear that factors influencing the capital structure decision of firms are many and differ from country to country and from one industry to another. Furthermore, it is also apparent that the influence of these factors on debt policy of firms is largely inconclusive, and thus requires further examination.

\section{Research Methodology}

Panel data methodology has been employed to achieve the objectives of this study. This methodology involves the pooling of cross-sectional units over several time periods and provides economic estimates that are not easily noticeable in pure cross-sectional or pure time series estimation analyses (Baltagi, 2005). Besides this, the technique allows the researcher to gain access to several observational units which increase the degree of freedom, reduce multi-collinearity among the independent variables and thus, leads to more efficient estimates. Published financial statements of listed manufacturing firms in Ghana, accessible in the archives of Ghana Stock Exchange and the web portals of the firms, have been used covering the period from 2000 to 2009. Due to the difficulty in accessing data on private manufacturing firms, the researcher focused exclusively on all seven listed manufacturing firms in Ghana. The choice of manufacturing firms was made because of the central role the sector plays in job creation and economic growth of nations (World Bank Report, 2007). To find out the determinants of debt policy of Ghanaian listed manufacturing firms, the following general formula, used by Kuznertsor and Muravyey (2001), has been adopted and modified:

$$
Y_{i t}=\alpha+\beta_{1} X_{i t}+e_{i t}
$$

Where

- $\quad Y$ is a capital structure measure.

- $\quad \alpha$ refers to time-invariant firm-specific effects.

- $\mathrm{X}$ is the independent variable.

- $\beta_{1}$ is the coefficient.

- Subscript $i$ is firm-specific at time $t$, respectively.

- $\mathrm{e}$ is the error term.

From equation one (1), equation two (2) below has been distinctively specified to investigate the determinants of capital structure choices of Ghanaian listed manufacturing firms. In estimating the model, the fixed effect estimation technique has been assumed.

$$
D R_{i t}=\beta_{0}+\beta_{1} S I Z E_{i t}+\beta_{2} P R O F_{i t}+\beta_{3} L I Q_{i t}+\beta_{4} A S_{i t}+\beta_{5} G R O_{i t}+e_{i t}
$$

Given that $\boldsymbol{\beta}_{0}$ is a constant while subscripts $i$ represent the cross-sectional element and $t$ denoting the time-series factor as indicated earlier, DR (which is the dependent variable) is a measure of debt ratios used to proxy the capital structure choice or the debt policy decision. It is decomposed into three (3) namely, and computed as:

Total debt ratio, defined as the ratio of total debt to total assets and follows Abor and Biekpe (2005); long-term debt ratio, defined as the ratio of long-term debt to total assets; and finally, short-term debt ratio, defined as a ratio of short-term debt to total assets.

The independent variables include firm size (SIZE) defined as the natural logarithm of total assets. The relationship between leverage and firm size is mixed. Several authors including Marsh (1987) and Rajan and Zingales (1995) find a positive association between leverage and firm size while Hijazi and Tariq (2006) observe an inverse relationship.

Furthermore, profitability (PROF) is defined as the ratio of earnings before interest and tax (EBIT) to total assets. Like size, the relationship between leverage and profitability is also inconclusive due to different theoretical underpinnings that prevail. For example, the pecking order theory posits that profitable firms use more retained earnings relative to debt. Thus, this theoretical underpinning implicitly predicts an inverse relationship between leverage and profitability. Empirically, several studies have supported this assertion. For example: Friend and Lang (1988), Hovakimian (2004), Hijazi and Tariq (2006) and Amidu (2007) have all observed an inverse relationship between leverage and profitability. On the other hand, the static-trade off theory argues that profitable firms use more debt relative to equity in their operations since debt use has interest tax shield advantage. In support of this theoretical underpinning, Abor and Biekpe (2005) and Akoto and Gatsi (2010) find a positive association between leverage and profitability of Ghanaian firms.

In addition, liquidity (LIQ) is defined as the ratio of short-term assets to short-term debt. Firms with higher liquidity ratios may use more debt relative to equity since their excess assets over the liabilities can serve as an 
incentive for them to use more debt. This suggests that there is a positive association between leverage and liquidity. Conversely, firms with high liquidity ratios may employ less debt in their operations since their excess assets can be used to finance positive net present value projects without resorting to debt (Ozkan, 2001). Thus, this suggests a negative relationship between leverage and liquidity.

Another independent variable is asset structure (AS), defined as the ratio of fixed assets plus stock to total assets. According to Harris and Raviv (1991), Bradley et al. (1984) and Titman and Wessels (1988), a firm with more tangible assets tends to have more debt in its capital structure and a higher liquidation value relative to its counterparts with lesser tangible assets. These findings suggest that there is a positive relationship between leverage and degree of tangibility. However, other authors including Kim and Sorensen (1986) find a significantly negative relationship between leverage and asset tangibility in their study.

Finally, growth opportunity (GRO) is defined as the ratio of intangible assets to total assets. From the pecking order theory of Myers and Majluf (1984), a firm with future growth prospects will prefer retained earnings relative to debt. Thus, this theory implies a negative relationship between leverage and growth opportunities. On the other hand, Michaelas et al. (1999) argue that leverage correlates positively with growth opportunities, especially short-term debt. The reason is due to the belief of management that, if future prospects are great, then their resultant cash flows can comfortably pay-off future debts of the firm, hence the incentive to use more debt. We indicate that the definition of all the above variables follow standard finance literature.

\section{Results and Discussions}

\subsection{Descriptive Statistics}

Table 1 shows the descriptive statistics of the variables used in the study, made up of the minimum, maximum, mean, standard deviation, and the variance. From the table, it can be seen that all the standard deviations are small relative to their means, with the exception of firm profitability. This illustrates that the data sets are close to their respective means.

Table 1. Descriptive statistics of variables used in the regression analysis

\begin{tabular}{|c|c|c|c|c|c|}
\hline Variables & Minimum & Maximum & Mean & Std. Deviation & Variance \\
\hline Total Debt Ratio (TDR) & 0.00 & 0.99 & 0.83 & 0.26 & 0.07 \\
\hline Long-term Debt Ratio (LDR) & 0.00 & 0.81 & 0.46 & 0.20 & 0.04 \\
\hline Short-term Debt Ratio (SDR) & 0.00 & 0.74 & 0.37 & 0.16 & 0.03 \\
\hline Firm size (SIZE) & 0.00 & 18.94 & 12.15 & 4.37 & 19.09 \\
\hline Profitability (PROF) & -0.23 & 0.32 & 0.04 & 0.11 & 0.01 \\
\hline Liquidity (LIQ) & 0.00 & 2.35 & 1.22 & 0.60 & 0.35 \\
\hline Asset Structure (AS) & 0.00 & 0.98 & 0.75 & 0.23 & 0.05 \\
\hline Growth opportunity (GRO) & 0.00 & 0.00 & 0.01 & 0.02 & 0.00 \\
\hline
\end{tabular}

Source: Authors' calculation.

The mean shows the averages of the variables used in the regression. From Table 1 above, the capital structure of Ghanaian listed manufacturing firms for the period 2000 to 2009 is made up of $83 \%$ debt and $17 \%$ equity. This is indicative of the fact that manufacturing firms in Ghana use more than four times debt than equity. It also implies that this level of capital structure poses a $26 \%$ risk to manufacturing firms as depicted by the standard deviation.

The firms' debt structure shows that, on average, $46 \%$ of long-term and $37 \%$ of short-term debt is used by Ghanaian listed manufacturing firms. Furthermore, it is worthy for us to note that the long-term debt component is entirely made up of long-term bank loans without any bonds. However, this is not surprising, given that the Ghanaian bond market is not developed. It is also clear from the table that the long term debt contributes more risk to the capital structure than short term debt since the standard deviation associated with long term and short term debts are $20 \%$ and $16 \%$ respectively. This supports the concept of cash flow valuation where distant cash flow is considered riskier that short-term ones. The average profitability over the period was $4 \%$ while growth was only $1 \%$. The liquidity of manufacturing firms, which determines whether they are able to meet their short term obligations or not, is well within a reasonable limit. 


\subsection{Regression Results}

The regression results in Table 2 shows the parameter estimates of the variables used in the study.

Table 2. Parameter estimates of factors influencing debt policy of listed manufacturing firms

\begin{tabular}{lccc}
\hline Variables & Total Debt Ratio & Short-term Debt Ratio & Long-term Debt Ratio \\
& TDR & SDR & -0.010 \\
\hline INTERCEPT & 0.077 & 0.086 & $(-0.157)$ \\
& $(1.259)$ & $(1.610)$ & 0.004 \\
Firm Size (SIZE) & $0.019^{* * *}$ & $0.014^{* *}$ & $(0.785)$ \\
& $(3.330)$ & $(2.814)$ & -0.079 \\
Profitability (PROF) & $0.505^{*}$ & $0.561^{* *}$ & $(-0.356)$ \\
& $(2.261)$ & $(2.850)$ & $0.150^{* * *}$ \\
Liquidity (LIQ) & 0.021 & $-0.127^{* * *}$ & $(3.608)$ \\
& $(0.504)$ & $(-3.452)$ & $0.294^{* *}$ \\
Asset Structure (AS) & $0.631^{* * *}$ & $0.339^{* * *}$ & $(2.634)$ \\
& $(5.633)$ & $(3.431)$ & $2.919^{* *}$ \\
Growth Opportunity (GRO) & 0.939 & $-1.873^{*}$ & $(2.450)$ \\
\hline F & $(0.786)$ & $(-1.778)$ & 0.548 \\
\hline Adjusted R & 0.730 & 0.431 & 0.512 \\
\hline
\end{tabular}

Source: Authors' calculation.

Note: $* *=$ Significant at $1 \%$ Level; $* *=$ Significant at $5 \%$ Level $*=$ Significant at $10 \%$ Level.

As highlighted in Table 2, there is a positive and statistically significant relationship between total debt and size. In this light, size is positive and significantly associated with short-term debt; and positive, but insignificantly in relation to long-term debt. These findings suggest that large listed manufacturing firms in Ghana use more debt in their operations. Specifically, these firms are more reliant on short-term sources to expand relative to long-term sources of financing. We also find a positive and statistically significant association between total debt and profitability, and also short term debt and profitability. However, the relationship between long-term debt and profitability is negative and statistically insignificant. This stands to reason as more short-term debt usage is essential for listed manufacturing firms in Ghana to be profitable. Furthermore, the study reports a negative and statistically significant relationship between short-term debt and liquidity but positive and statistically significant association between long-term debt and liquidity. Thus, listed manufacturing firms in Ghana will be unable to meet their liquidity obligations efficiently, when they rely more on short-term debt to finance their operations relative to long term debt. The regression results further indicate positive and statistically significant relationships between total debt, short-term debt, long-term debt and the firms' asset structure. This means that Ghanaian listed manufacturing firms use more debt in their capital structure when they intend to increase their fixed assets and stocks. Finally, we find negative and statistically significant relationship between short-term debt and growth but positive and statistically significant relationship between long-term debt and growth. Thus, Ghanaian listed manufacturing firms employ more long-term debt to invest in intangible assets to enable them to grow. However, these firms cannot exploit short-term sources of financing to achieve the same.

\section{Conclusions and Implications}

Though listed manufacturing firms in Ghana generally use more long-term sources of financing than short-term sources, the firms tend to be more reliant on short-term financing when specifically acquiring assets to expand and become profitable (Akoto \& Gatsi, 2010; Amidu, 2007; Abor, 2005). The reason may be due to the under development of the Ghanaian capital market (both bonds and equity) coupled with high lending rates charged by 
Ghanaian banks on long-term loans. Since the over-reliance on short-term sources of financing the firm can pose short-term liquidity challenges, the Ghanaian government must intervene by putting policy frameworks in place aimed at developing the country's capital markets. Other policy tools, such as moral suasion and the like, can also be employed by the Bank of Ghana (BoG) to regulate the long-term lending rate of the banks. This is possible given the low and stable inflation rate Ghana has enjoyed (around 9\%) since the year 2009. Furthermore, listed manufacturing firms in Ghana can enhance their financial and operating performance by accessing capital from other foreign capital markets.

\section{References}

Abor, J. (2005). The effect of capital structure on profitability: an empirical analysis of listed firms in Ghana. The Journal of Risk Finance, 6(5). http://dx.doi.org/10.1108/15265940510633505

Abor, J., \& Biekpe, N. (2005). What Determines the Capital Structure of Listed Firms in Ghana? Africa Finance Journal, 7(1), 37-48.

Akoto, R. K., \& Gatsi, J. G. (2009). Capital Structure and Profitability in Ghanaian Banks. Social Science Research Network, 1(2), 66-70.

Amidu, M. (2007). Determinants of Capital Structure of Banks in Ghana: An Empirical Approach. Baltic Journal of Management, 2(1), 67-79. http://dx.doi.org/10.1108/17465260710720255

Annual Survey of Manufactures in Ghana. (2006).

Antonious, A., Guney, Y., \& Paudyal, K. (2002). Determinants of Corporate Capital Structure: Evidence from European Counties. Journal of Economics.

Baltagi, B. H. (2005). Econometric Analysis of Panel Data (3rd ed.). Chichester: Wiley.

Bradley, M., Jarrel, G. A., \& Han Kim, E. (1984). On the Existence of an Optimal Capital Structure: Theory and Evidence. The Journal of Finance, 39, 857-880. http://dx.doi.org/10.1111/j.1540-6261.1984.tb03680.x

Brigham, E., \& Ehrhardt, M. (2008). Financial Management: Theory and Practice (12th ed.). USA: Thomson Learning.

Deesomsak, R., Paudyal, K., \& Pescetto, G. (2004). The determinants of capital structure: evidence from the Asia Pacific region. Journal of Multinational Financial Management, 14, 387-405. http://dx.doi.org/10.1016/j.mulfin.2004.03.001

De Jong, A., Kabir, R., \& Nguyen, T. T. (2008). Capital Structure around the World: the Roles of Firm- and Country-Specific Determinants. Journal of Banking and Finance, 32, 1954-1969. http://dx.doi.org/10.1016/j.jbankfin.2007.12.034

Demirguc-Kunt, A., \& Levine, R. (2007). Finance and Economic Opportunity. Policy Research Working, Paper 4468. World Bank, Washington, D.C.

Frank, M. Z., \& Vidhan, K. G. (2005). Capital Structure Decisions. Working Paper. University of Minnesota \& Hong Kong University of Science and Technology.

Friend, I., \& Lang, H. P. (1988). An empirical test of the impact of managerial self-interest on corporate capital structure. Journal of Finance, 43, 271-281. http://dx.doi.org/10.1111/j.1540-6261.1988.tb03938.x

Ghana Stock Exchange Fact Book. (2005).

Ghana Stock Exchange Fact Book. (2010).

Harris, M., \& Raviv, A. (1991). The theory of capital structure. Journal of Finance, 46(1), 297-355. http://dx.doi.org/10.1111/j.1540-6261.1991.tb03753.x

Hijazi, S. T., \& Tariq, Y. B. (2006). Determinants of capital structure: a case for Pakistan cement industry. Lahore Journal of Economics, 11(1), 63-80.

Hovakimian, A., Hovakimian, G., \& Tehranian, H. (2004). Determinants of target Capital Structure: The case of dual debt and equity issues. Journal of Financial Economics, 71(3). http://dx.doi.org/10.1016/S0304-405X(03)00181-8

Kim, W. S., \& Sorensen, E. H. (1986). Evidence on the Impact of the Agency Costs of Debt on Corporate Debt Policy. The Journal of Financial and Quantitative Analysis, 21(2), 131-144.

Kuznetsor, P., \& Muravyev, A. (2001). Ownership Concentration and Firms Performance in Russia: The Case of Blue Chips of the Stock Market. Journal of Business Economics, 51(4), 469-488. 
Marsh, P. (1982). The Choice between Equity and Debt: An empirical study. Journal of Finance, 37(1), 121-144. http://dx.doi.org/10.1111/j.1540-6261.1982.tb01099.x

Michaelas, N., Chittenden, F., \& Poutziouris, P. (1999). Financial Policy and Capital Structure Choice in U.K. SMEs: Empirical Evidence from Company Panel Data. Small Business Economics, 12(2), 130-133. http://dx.doi.org/10.1023/A:1008010724051

Modigliani, F., \& Miller, M. (1958). The cost of capital, corporate finance and the theory of investment. American Economic Review, 48, 261-297.

Modigliani, F., \& Miller, M. (1963). Corporate income taxes and the cost of capital: a correction. American Economic Review, 53, 443-453.

Myers, S. C., \& Majluf, N. S. (1984). Corporate Financing and Investment Decisions when firms have Information that Investors do not have. Journal of Financial Economics, 13(2), 187-221. http://dx.doi.org/10.1016/0304-405X(84)90023-0

Ozkan, A. (2001). Determinants of capital structure and Adjustment to Long Run Target: Evidence from U.K Company Panel Data. Journal of Business Finance and Accounting, 7, 77-79.

Rajan, R. G., \& Zingales, L. (1995). What do we know about Capital Structure? Some Evidence from $\begin{array}{llll}\text { International Data. Journal of } & \text { Finance, } & \text { 50(5), }\end{array}$ http://dx.doi.org/10.1111/j.1540-6261.1995.tb05184.x

Rao, S. M., Waters, S. M., \& Payne, B. (1995). A financial Profile. Journal of Financial and Strategic Decision, $8(3)$.

Titman, S., \& Wessels, R. (1988). The determinants of capital structure choice. Journal of Finance, 43(1), 1-19. http://dx.doi.org/10.1111/j.1540-6261.1988.tb02585.x

Wolfgang, D., \& Fix, R. (2003). What are the Determinants of the Capital Structure? Some Evidence from Switzerland. Swiss Journal of Economics and Statistics, 141(I), 71-113.

World Bank Annual Report. (2007).

\section{Copyrights}

Copyright for this article is retained by the author(s), with first publication rights granted to the journal.

This is an open-access article distributed under the terms and conditions of the Creative Commons Attribution license (http://creativecommons.org/licenses/by/3.0/). 